\title{
A VSM improvement-based approach for lean operations in an Indian manufacturing SME
}

\author{
Aayush Saboo \\ Warwick Manufacturing Group, \\ International Manufacturing Centre, \\ The University of Warwick, \\ Coventry, CV4 7AL, UK \\ E-mail: aayushsaboo@gmail.com
}

\section{Jose Arturo Garza-Reyes*}

Centre for Supply Chain Improvement,

The University of Derby,

Kedleston Road Campus,

Derby, DE22 1GB, UK

E-mail: J.Reyes@derby.ac.uk

*Corresponding author

\author{
Ahmet Er \\ Warwick Manufacturing Group, \\ International Manufacturing Centre, \\ University of Warwick, \\ Coventry, CV4 7AL, UK \\ E-mail: A.Er@warwick.ac.uk

\section{Vikas Kumar} \\ Dublin City University Business School, \\ Dublin City University, \\ Dublin City, Ireland \\ E-mail: vikas.kumar@dcu.ie
}

\begin{abstract}
The current economic environment in the Indian manufacturing industry is offering a perfect opportunity to SMEs of this country to develop and grow by acting as suppliers of large multinational original equipment manufacturers (OEMs). To meet the challenge of offering high standards of quality, cost and delivery (QCD) to these multinational OEMs, Indian manufacturing SMEs must implement effective approaches, such as lean manufacturing, to continually and systematically improve their operations. However, the academic literature indicates that the adoption of lean manufacturing and some of its tools, such as value stream mapping (VSM), by Indian manufacturing SMEs is feeble, or in many cases lean initiatives have been unsuccessful. This paper presents a successful application of VSM in an Indian manufacturing SME. The results of the study and operational improvements achieved indicate that the application of VSM is an effective
\end{abstract}


strategy for organisations of this type to improve their processes and thus meet their current challenges. This paper contributes by providing empirical evidence of the application of VSM in India and thus it can be used as a guiding reference for managers and engineers to undertake specific process improvement projects, in their organisations, similar to the one presented in this paper.

Keywords: India; lean operations; manufacturing; SME; value stream mapping; VSM.

Reference to this paper should be made as follows: Saboo, A., Garza-Reyes, J.A., Er, A. and Kumar, V. (2014) 'A VSM improvement-based approach for lean operations in an Indian manufacturing SME', Int. J. Lean Enterprise Research, Vol. 1, No. 1, pp.41-58.

Biographical notes: Aayush Saboo is a Manufacturing Manager and Engineer. $\mathrm{He}$ is currently involved in the development, management and optimisation of manufacturing facilities and processes, for various industries and products, in India. He completed his first degree at the Thapar Institute of Engineering and Technology in India, and then an MSc in Manufacturing Systems Engineering at Warwick Manufacturing Group (WMG), The University of Warwick, UK. His current professional and research interests include the improvement of processes and products by implementing lean management concepts and tools, and to streamline the development of new products from their initial conception until they are lunched into the market.

Jose Arturo Garza-Reyes is a Senior Lecturer in Operations and Supply Chain Management at the Centre for Supply Chain Improvement, Derby Business School, the University of Derby, UK. He has published a number of articles in leading international journals and conferences and two books in the areas of quality management systems and manufacturing performance measurement systems. He is a co-Founder and Editor of the Int. J. of Supply Chain and Operations Resilience (IJSCOR), and has participated as guest editor for special issues in various international journals. His research interests include general aspects of operations and manufacturing management, operations and quality improvement, and supply chain improvement.

Ahmet Er is an Associate Professor with Warwick Manufacturing Group (WMG) of the University of Warwick, UK. Currently, he is primarily occupied with the management of a major MSc programme including courses such as manufacturing systems engineering, engineering business management, supply chain and logistics management, industrial process business management and others. He also teaches subjects such as manufacturing technology and machining. His current research interest is mainly centred around supporting and supervising MSc student research projects in the areas of materials, manufacturing processes, manufacturing systems and lean manufacture. He is a Fellow of the Institute of Materials, Minerals and Mining.

Vikas Kumar is a Lecturer in Management at Dublin City University Business School, Ireland. He has published more than 40 articles in leading international journals and international conferences including the International Journal of Production Research, Computers \& Industrial Engineering, and Production Planning \& Control. He serves on the editorial board of six international journals including Int. J. of Services, Economics and Management, I. J. of Manufacturing Systems, I. J. of Lean Enterprise Research, and I. J. of Network and Mobile Technologies. His current research interests include healthcare management, supply chain management, process modelling, operations strategy, and service operations management. 


\section{Introduction}

Singh and Ahuja (2012) comment that in the last decade the business environment of India has suffered a radical change. One of the reasons that may have contributed to this change is the fact that the global market today is trying to establish its base in India (Garza-Reyes et al., 2012). Thus, since the start of the 21 st century the Indian economy has been growing at a healthy rate. This healthy growth rate coupled with a large population has led to an increase in demand of consumer products. As a consequence, the high potential of the domestic Indian market has attracted leading manufacturers from across the globe. In particular, a study conducted by Ernst \& Young and the Automotive Component Manufacturers Association (ACMA) concluded that the Indian automobile industry is forecast to become a 9 million-unit industry by 2020 (Rajenthirakumar and Thyla, 2011). However, to achieve a market size of 9 million units the Indian car industry requires the addition of manufacturing capacity for all automobile parts. This would lead to an increase in growth opportunities for manufacturing companies. The large original equipment manufacturers (OEMs) are now focusing on their core strengths and increasing the outsourcing of secondary jobs. To save costs and increase profitability, the secondary jobs are generally outsourced to small and medium enterprises (SMEs), which have lower overhead costs and can maintain and provide competitive prices. The increase in the outsourcing activity has created a beneficial and profitable business opportunity for SMEs in India. For this reason, India has seen an increase, over the last decade, in the number of SMEs that are supplying components and assemblies to OEMs. Various business groups have diversified and setup component manufacturing facilities as tier 1 suppliers for automobile OEMs. The SME organisation studied in this paper has also followed the same path and diversified into component manufacturing. This organisation was established in 1965, and is a family managed industrial conglomerate with interest in varied sectors. In 2005, it established a manufacturing facility in the North Indian state of Himachal Pradesh to manufacture sheet metal and plastic injection moulding components. The facility was specifically established to capture the excellent opportunity available in the OEM component supplier segment. However, the bidding for OEM contracts has turned very aggressive due to the lucrative nature of these contracts. For an SME to successfully compete for and complete these competitive contracts, it is necessary to guarantee quality, cost and delivery (QCD) (Khan et al., 2007). Arguably, it is not only necessary for SMEs to guarantee QCD but they should also be able to continually and systematically improve them.

Over the years different manufacturing philosophies have been developed to help organisations in continually and systematically improve QCD. Each philosophy has its own merits and limitations and they are applied based on their suitability for a specific organisation. 'Lean manufacturing' is one such philosophy that has been successfully implemented and applied by organisations to improve operations and QCD. According to Dankbaar (1997), lean manufacturing is a system that by making optimum use of employees' skills and focussing on continual improvement is able to produce a high variety of products at lower cost with better quality and at the same time consumes lesser of every resource when compared to traditional manufacturing methods. On the other hand, Sahoo et al. (2008) comment that lean manufacturing is "an approach used for constructing, operating, managing and continuously improving industrial manufacturing systems with the use of standard lean tools and techniques, which include value stream mapping (VSM), kaizen, 5S, single minute exchange of die (SMED), just-in-time (JIT), 
Kanban and observation". Anand and Kodali (2008) suggest that many companies in India, specially manufacturing ones, are now implementing the lean philosophy as an approach to improve productivity and internal efficiency, see for example: Singh and Sharma (2009), Dhandapani et al. (2004), Kumar et al. (2006), Vinodh et al. (2010), Upadhye et al. (2010) and Bhamu et al. (2012). Furthermore, a study carried out by Ghosh (2013) indicated that out of 72 Indian manufacturing plants surveyed, $80 \%$ of them had implemented lean, or at least some of its principles and/or tools. However, although there is some evidence that indicates that lean manufacturing has been applied by Indian manufacturing companies in order to increase their competitiveness and improve QCD, Singh et al. (2010) comment that the "Indian industry is still struggling to implement lean principles and philosophies". In addition, a study conducted Garza-Reyes et al. (2012) indicated that lean manufacturing is not the most 'popular' approach used by Indian organisations as companies in this country have given preference to the implementation of quality improvement approaches such as ISO standards, total quality management (TQM) and Six Sigma over lean manufacturing. Eswaramoorthi et al. (2011) also found that "the status of lean implementation in the Indian machine tool sector is still in infant stage".

Since the evince found in the academic literature can be considered contradictory and inconclusive in relation to the implementation of lean manufacturing principles in the Indian manufacturing sector, this paper presents a case study of the successful application of lean manufacturing, and more specifically VSM, in an Indian manufacturing SME. Thus, this paper intends to contribute by proving evidence that nowadays the application of lean manufacturing in the Indian manufacturing sector is a reality, and that this application could help the SMEs of this country to take full advantage of the economic development of India by effectively and efficiently aiding them in supplying their OEMs' contracts. In addition, the value of this paper also lies in the fact that it can be used as a guiding reference and model for managers and engineers to undertake specific process improvement projects, in their organisations, similar to the one presented in this paper.

\section{The concept of 'value' and VSM}

A cornerstone of the lean manufacturing philosophy is the concept of 'value'. For a manufacturing firm it is important to clearly define 'value' from the point of view of the customer. A clear definition of customer's view of value is important because customers will only pay for what they recognise as valuable and not for what the manufacturer thinks as valuable. Womack (2006) stresses that a customer is concerned only with the value addition directed at them and not in the average of the firm's effort in general. For this reason, Chernatony et al. (2000) comment that authors such as Band (1991), Gale (1994) and Naumann (1995) have highlighted the element of 'value added (VA)' as a strategy for achieving competitive advantage and have also advised organisations on designing processes that create value for their customers.

A product goes through various stages before it is transformed into a form where it can be sold. In this context, value is added at various stages through this transformation process, which is also known as a value stream. A value stream is comprised of all the process activities and/or operations, both VA and non-value added (NVA), that are required to bring a product or a group of products from raw materials to the arms of the customer (Houten et al., 2012). Every product has a different value stream, and a 
customer only focuses on the value stream of its product. Hence it becomes essential for a firm to pay attention to different value streams and improve them, which would prove advantageous to both the firm and the customer. However, for a firm to be able to improve the value stream of its products it is first necessary to fully understand it. VSM is a lean manufacturing's visualisation tool which can aid this task by showing the flow of material along with information as the product passes through the transformation process (Rother and Shook, 1999).

Manos (2006) mentions that the credit for introducing VSM to the world goes to Toyota Motor Company (TMC), as VSM is based on the material and information flow diagrams traditionally used by the Toyota Production System (TPS). It was Rother and Shook (1999) who first introduced and discussed the VSM tool, as known today, in their book Learning to See. Since then, various authors have defined VSM in different ways. According to Manos (2006), VSM is a platform that enables firms to identify and improve various product families. Rother and Shook (1999), on the other hand, define VSM as a pencil and paper tool that helps to comprehend the information and material flow throughout the production process of a product. In general, Rother and Shook (1999) suggest the conduction of the following four stages when undertaking a VSM study:

1 selecting a product family

2 constructing a current state value stream map

3 establishing the future state value stream map

4 implementing the future state value steam map.

The first step requires selecting a product family. A firm may have multiple product types that undergo different processing steps, but Rother and Shook (1999) advice against mapping all product families at once, as this will only make the VSM complicated. Womack (2006) comments that carefully choosing a product family for VSM would increase the benefits expected from the VSM analysis. The second step is to map the current state of the value stream. This should be initiated by agreeing upon the problem statement and forming a cross-functional team with representation from all departments (Rother and Shook, 1999; Lovelle, 2001). Once this is done, the next step involves walking through the value stream to draw a map of the process. Rother and Shook (1999) suggest observing the process starting from the shipping department and then working backwards; this provides a better understanding of material and information flow. Tapping et al. (2002) emphasise the criticality of mapping an accurate current state. They reason that as the future state and any recommendations for improvement are based on the current state, it becomes increasingly important to map it correctly.

The third step in VSM is to draw the proposed future state value stream map. Before starting to draw the future state, it is essential to calculate the 'takt' time based on customer demand. This is essential because all further suggestions and improvements are based on takt time. Also based on the takt time, bottlenecks in the value stream can be identified and treated with lean tools to reduce cycle time $(\mathrm{C} / \mathrm{T})$ to within the takt time levels. Womack (2006) mentions that while drawing the future state map it is essential to implement continuous flow through as many activities as possible. This reduces costs and throughput time, which leads to benefits for both the firm as well as the customer. In instances, to implement continuous flow it may be essential to perform layout changes or 
adopt new technology, which may require longer time durations for the VSM study. Seth and Gupta (2005) also mention the importance of line balancing and output levelling during future state mapping.

Once the future state value stream map is prepared, which actually represents the 'ideal' state in which the value stream should function, the final step in VSM is to make and implement a work plan to close the gap between the future state and current state (Rother and Shook, 1999). The work plan is made using various lean tools and techniques to take the current state towards the ideal situation.

VSM has been used in both manufacturing and service industries; however, its application is more predominant in manufacturing (Houten et al., 2012). According to Gurumurthy and Kodali (2011), this is because lean has been more widely applied in the manufacturing industry and therefore more recorded research is available in this sector. Examples of reported applications of VSM in the manufacturing industry are presented in Table 1. A common element in all the studies presented in Table 1 is the fact that VSM has been predominantly applied for productivity improvement in all these organisations. Gurumurthy and Kodali (2011) comment that although VSM has been traditionally used for productivity improvements, in recent times it has also been applied for other purposes such as improving leadership, perform benchmarking, and increase value across the supply chain.

Table 1 Examples of the application of VSM

\begin{tabular}{llcc}
\hline No. & Year & Manufacturing industry & Reference \\
\hline 1 & 2000 & Steel component supplier & Brunt (2000) \\
2 & 2002 & Electric motors & McDonald et al. (2002) \\
3 & 2005 & Motorcycle frames & Seth and Gupta (2005) \\
4 & 2007 & Steel manufacturer & Abdulmalek and Rajgopal (2007) \\
5 & 2008 & Telephony products & Lasa et al. (2008) \\
& & (plastic injection moulding) & \\
6 & 2008 & CNC vertical machining centres & Ramesh et al. (2008) \\
7 & 2008 & Forging & Sahoo et al. (2008) \\
8 & 2009 & Crank shaft gear & Singh and Sharma (2009) \\
9 & 2010 & Industrial switchboards and switchgears & Chen et al. (2010) \\
10 & 2010 & Camshaft & Vinodh et al. (2010) \\
11 & 2011 & Automotive metal component supplier & Rajenthirakumar and Thyla (2011) \\
\hline
\end{tabular}

Similarly as with the application of lean manufacturing, although the academic literature shows some evidence of the use of VSM in the Indian manufacturing industry, it also indicates that organisations in this country have given preference to the use of other lean tools such as kaizen, Total Productive Maintenance, and 5S (Vinodh et al., 2010; Garza-Reyes et al., 2012). Thus, Vinodh et al. (2010) consider the implementation of VSM in India as feeble. This motivated the researches to undertake this project. 


\section{VSM study - current state map}

\subsection{Product family selection, formation of cross-functional team and definition of problem}

The Indian manufacturing SME studied produces a number of different types of products from its sheet metal department. These include products for consumer goods, passenger cars, telecom industry and heavy trucks. As commented by Rother and Shook (1999) and Womack (2006), it is essential to select a product family before starting the VSM. For this study the product family of truck bumpers was chosen. This product is made up of the assembly of 4 different components manufactured 'in-house' (i.e., end cap, c-channel, end cap for c-channel, mounting plate) and 1 outsourced component (i.e. ERW pipe), which are assembled following a manufacturing process that consists of 13 operations (i.e., pipe cutting, sheet shearing, stamping, bending, welding, grinding, inspection, pre-treatment, powder coating and baking, liquid painting, drying, packing, despatching). The product serves the purpose of a rear protection device in a truck and it is supplied to an OEM operating in the heavy truck industry. The selection of truck bumpers as the product family to VSM in this study was based on the following factors:

1 it is the biggest product family in terms of turnover for the organisation studied

2 the customer had indicated increasing volumes over the following years

3 the company was facing delivery problems with this product

4 the manufacturing process of this specific product involved the use of all major equipment in the sheet metal division; hence it increased the scope and impact of the VSM improvement.

After selecting and justifying the product's family considered for the VSM improvement project, a cross-functional improvement team was formed as suggested by Lovelle (2001). The members were selected in a manner to form a team with working knowledge of all aspects of the product's family previously selected. The first agenda for the team before starting the VSM study was to agree on the actual problem to be solved. Womack (2006) points out that it is important for a firm to agree upon the actual problem before starting a VSM exercise, because without a clear goal the actual issues of the process would not be focused upon through the VSM. This ensured a unilateral focus of the team during the process of VSM. The team, in consultation with the management, decided the followings as the main objectives to be achieved through the VSM study undertaken:

1 reducing production lead time

2 reducing in-process and finished goods inventory

3 reducing process bottlenecks with respect to customer demand. 


\subsection{Data collection and drawing the current state map}

The collection of data for the current state map followed the recommendations of Rother and Shook (1999) of starting the mapping at the shipping department and working backwards through each manufacturing process until they reached the raw material entry point, collecting snapshot data at each stage. As recommended by Brunt (2000), the team ensured that the whole process was mapped and that the work was not divided into parts; this ensured consistency in the data collected. In order to draw the current state process map, the team used an A3 sheet and pencil while it was walking through the production process to collect data (Brunt, 2000) and the VSM icons as specified by Rother and Shook (1999) in Learning to see.

Ramesh et al. (2008) mention that a unique feature of VSM, which distinguishes it from other process analysis techniques, is the fact that in a VSM both material and information flows are presented together, and shown in reference to the customer's demand. Thus, information flow, material flow and customer demand data related to the product studied was captured to draw a realistic current state map.

Information flow includes information that tells each process what to produce and when to produce it (McDonald et al., 2002). In this case, specific information that included weekly and daily production and machine schedule, requirements of raw material, suppliers' lead time and daily shipping schedules were collected from the planning, production and control (PPC) department of the organisation studied.

On the other hand, material flow captures various characteristics of the manufacturing process and provides important insights required for mapping the current state. The following information was collected from the production process:

1 process $\mathrm{C} / \mathrm{T}$

2 inventory levels before each stage (work-in-process - WIP)

3 machine availability

4 change over time

5 number of operators involved

6 number of shifts operated.

This information was collected using principles of work measurement and industrial engineering (i.e., time and motion study) as all the process operations from which this data was collected fell under the category of repetitive work.

For the process $\mathrm{C} / \mathrm{T}$, the actual reading was taken using a calibrated stopwatch. As per recommendation of Slack et al. (2009) and Baines (1995), the measurements were taken after the operators had settled down and regular flow of work had begun. Readings were taken on the same day in sets of three readings at three times during the day - 30 minutes after start of production, 30 minutes after lunch break and 30 minutes before finishing time. It was also ensured that the same operator was present at each of the three times. The results were then averaged and used for further analysis. For some operations (i.e., powder coating and pre-treatment), the $\mathrm{C} / \mathrm{T}$ collected were based on recorded averages available in the production department, these could not be physically verified as both of these operations were not running on the day of the data collection. 
Figure 1 Current state value stream map (see online version for colours)

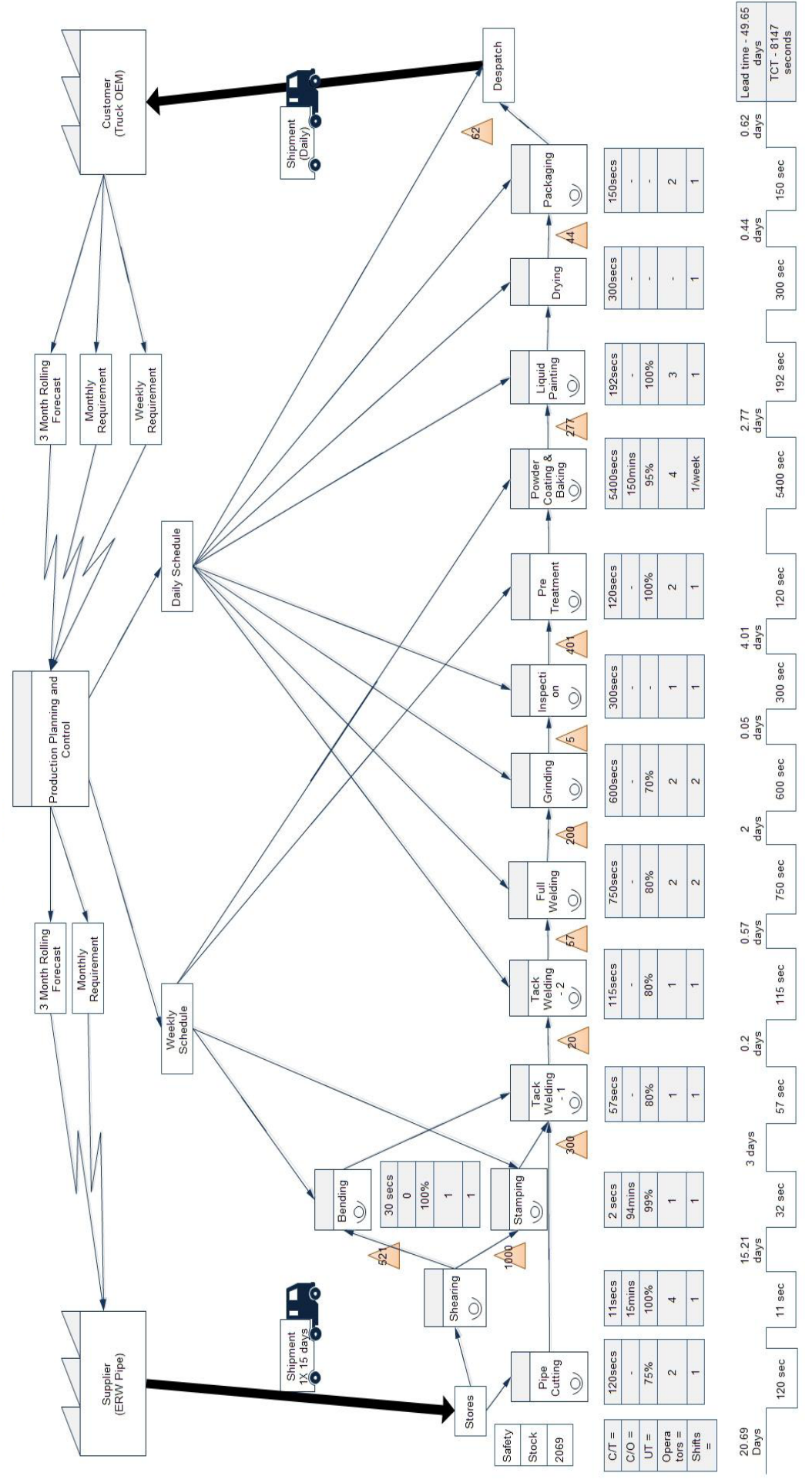


In the case of the changeover time, the data was collected from the logs maintained by the sheet metal division and not based on actual observations. This was because on the day of the data collection, there were no changeovers. The WIP level between operations was determined by observing, counting and recording the average number of units present at each station. It was ensured that store and other areas of the factory were also searched for work-in-progress (WIP) material related to the product's family studied. The machine availability signifies the amount of time a machine was operating; in this case, it excluded downtime due to unplanned breakdowns from the total available time. Machine availability was collected from the maintenance log recorded over the last six months. Data related to the number of operators and shifts worked was taken from each department's head and it was cross-verified with records maintained by the Human Resources department. The manufacturing facility operated on a six-day working week pattern and employed 1 shift of 8 hours each, with a lunch break of 30 minutes. As and when required, overtime was carried out, but it had to be authorised by the factory manager.

Finally, the customer demand was predictive to be 2,500 units (100 units every working day). An analysis of a previous year's demand revealed that the customer's demand had very limited variability. Thus, this monthly forecast quantity was considered as the demand for all further analyses. Once the team gathered all the above data, the next step was to finalise the current state map by making the necessary changes to the first version, which was drawn using pencil and paper. The current VSM is shown in Figure 1.

\subsection{Analysis of current state VSM}

After capturing the information flow and representing it in the VSM it was evident that a 'push'-based system was followed by the organisation studied as each operation in the production process functioned independently of the upstream or downstream operations. Every process from purchase to despatch functioned according to information and instructions received from the PPC department, as evident in Figure 1. 'Pull' or continuous flow was not practised in any part of the manufacturing process.

It is the analysis of the material flow characteristics the most essential and critical to develop and achieve a desirable future state, therefore a lot of attention to detail was given during this process.

\subsubsection{Cycle time}

The $\mathrm{C} / \mathrm{T}$ presented in the data boxes below each operation, see Figure 1, represents the processing time at each stage. Though the processing time is made of 3 different types of activities (i.e., VA, NVA, and NVA but necessary), in this study only the total C/T of each process was considered. Figure 1 shows that there was a vast difference between the $\mathrm{C} / \mathrm{T}$ of the different operations involved in the value stream; times varied from 2 seconds for stamping to 5400 seconds for powder coating. The vast difference in $\mathrm{C} / \mathrm{T}$ showed that it was difficult to maintain a continuous flow through the value stream. This was because stamping would produce at a much higher rate than what its downstream processes could consume, which would lead to an increase in inventory in processes downstream of stamping. In contrast, if inventory was not to be increased, then stamping had to slow the 
production rate, which would involve the under utilisation of the stamping operation. This showed that a push-based system of material flow was used in the value stream of the product studied. It was also important to calculate the total $\mathrm{C} / \mathrm{T}$, which is the sum of $\mathrm{C} / \mathrm{T}$ of all processes. This was found to be 8147 seconds.

\subsubsection{Production lead time}

Production lead-time indicates the time taken for a piece of raw material to be processed, converted into a finished product and finally being shipped to a customer. It is an important parameter to judge the overall efficiency of any manufacturing process. The current lead-time for the process studied was 49.65 days, this includes total processing and waiting time. Waiting time was calculated based on the inventory present before each stage. An important measure of process efficiency is given by a representation of the total $\mathrm{C} / \mathrm{T}$ as a percentage of the production lead-time (i.e., total $\mathrm{C} / \mathrm{T} /$ production lead time). In this case, it was found to be $0.2 \%$ approximately. This showed that out of the total leadtime of 49 days only less than $1 \%$ is processing time and the rest is waiting time. Such a low figure indicated immense waiting time in the value stream, mainly due to high inventory before most processes. Also, the vast differences in $\mathrm{C} / \mathrm{T}$ also led to an increase in waiting time.

\subsubsection{Inventory}

The triangles before a process in the current state map in Figure 1 show the amount of inventory that is available before the studied operations. The inventory was also converted to time. This was achieved by dividing the amount of inventory present at each operation by the daily customer requirement. In this case, the daily customer demand was considered as 100 units/day, which is the future expected demand. The process presented high inventory in each stage, with inventory as high as 20 days before the pipe cutting operation. High levels of inventory increase the probability of inherent defects in the manufacturing system as it covers for number of process defects (Womack et al., 1990; Shingo, 1997). It also has a negative impact on cash flow and occupies valuable and costly floor space (Kilpatrick, 2003).

\subsubsection{Takt time and bottle neck operations}

Takt time is the production rate required to timely meet customer demand. Hines et al. (1998) consider takt time as the most important parameter, based on which the future state of any value stream is modelled. It is calculated by dividing the 'available working time per day' by the 'customer demand per day' (McDonald et al., 2002). Considering that the company operated one shift of 8 hours with a lunch break of 30 minutes, 25 days/month and that the customer demand was 100 units/day, the takt time was calculated to be $270 \mathrm{sec} /$ unit. Figure 2 illustrates the operations' $\mathrm{C} / \mathrm{T}$ in relation to the takt time. Powder coating was omitted as it had a very high $\mathrm{C} / \mathrm{T}$ and could not be shown on the same graph. Figure 2 shows that full welding, grinding, inspection, drying and powder coating (not in the graph), had $\mathrm{C} / \mathrm{T}$ higher than the takt time and hence all these operations required improvements or capacity addition to meet customer demand. 
Figure 2 Process operations C/T vs. takt time (see online version for colours)

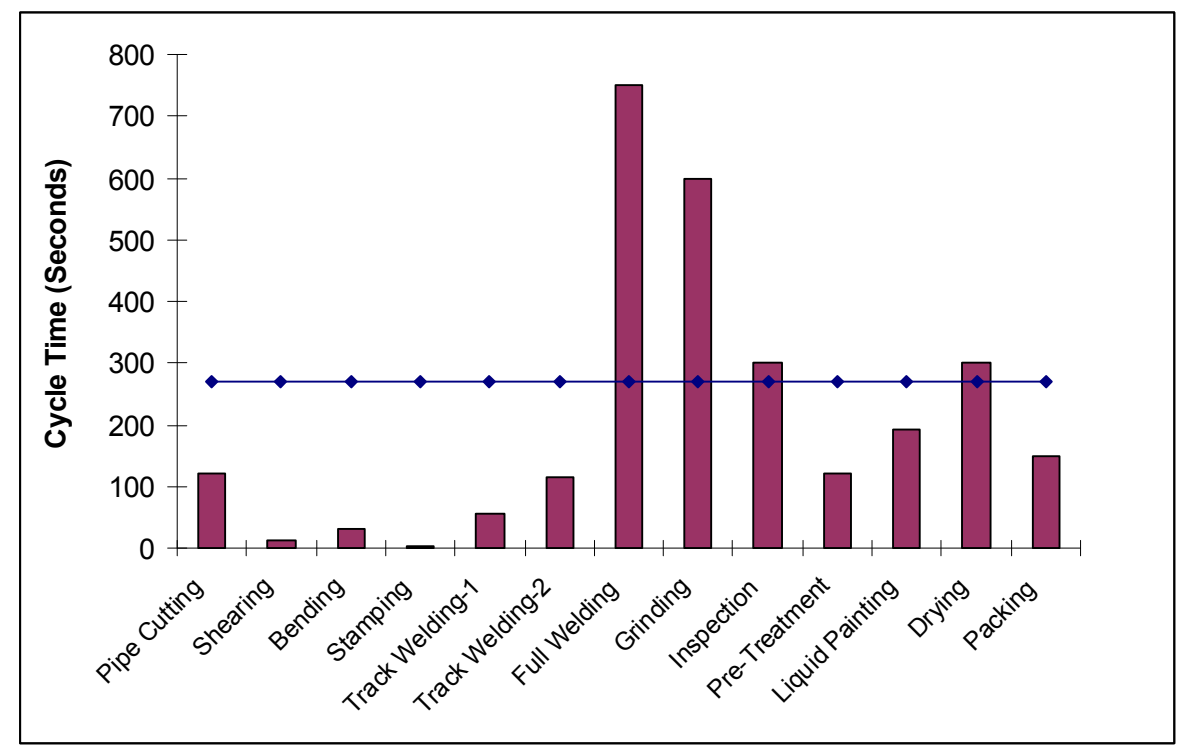

\section{VSM study - future state map}

In VSM, the current state map helps in developing a snapshot to understand the business operations; it shows the 'as-is' situation of a business. But the actual effectiveness of VSM is its ability to envision and develop a value stream that depicts the ideal state of a value stream process. The future state VSM enables businesses to look into the future and understand the best way of operating a value stream (Brunt, 2000). To develop a future map a systematic approach should be followed to gain maximum benefit from the VSM methodology. In this context, a systematic approach is proposed by Rother and Shook (1999) in Learning to See, which is based on answering a set of questions. These questions were taken as a base to guide the construction of the future state VSM, which is shown in Figure 3.

The proposals made and implemented by the improvement team in order to reduce/eliminate the issues in the manufacturing process highlighted by the current state map and that were able to close the gap between the current state of the manufacturing process and its desired state were as followed:

- A safety stock of the family of products studied was decided to be built and implemented as a permanent element of the production process studied. This was due to the component studied is a critical part that the organisation could not afford to default in its timely delivery, as this is the starting phase of its relationship with its customer.

- A kanban system was implemented to determine the need of production at the upstream step of packaging and liquid painting. Material was delivered in trolleys and each trolley was able to hold 20 components, therefore it was decided to use 20 as the kanban size for despatch. 
- Tack welding-1, tack welding-2, full welding and grinding were re-arranged into a cell. The total welding operation which initially consisted of 3 operations was rearranged into 2 operations carried out by 2 teams of 2 welders each, whereas 2 operators were assigned to the grinding operation. A ' 5 why' analysis indicated that poor skills of welding operators and low capacity of the grinder machines resulted in a very high $\mathrm{C} / \mathrm{T}$ of 1,522 seconds. This $\mathrm{C} / \mathrm{T}$ was reduced to 810 seconds by providing appropriate training to the welding operators and acquiring new grinding equipment, which also helped to reduce the individual C/T of these operations to 270 seconds.

- Since the operations of stamping, shearing, bending and pre-treatment were shared with other product families and thus were not available to the product family studied $100 \%$ of the time, these were recommended not to be re-arranged into cells with other operations.

- The inspection operation initially located between the grinding and pre-treatment operations was eliminated by implementing poka-yokes, jigs, and fixtures in all welding operations.

- The improvement team suggested the acquisition of a smaller batch type booth and baking oven to reduce the $\mathrm{C} / \mathrm{T}$ of the powder coating and liquid coating operation. Once that the new equipment was installed, powder coating, liquid coating, drying and packing were re-arranged in a cellular layout with continuous flow implemented across it. As shown in Figure 2, C/T of liquid painting and drying were close to the takt time and with the acquired equipment the times of powder coating and baking were also brought to the same levels.

- A significant reduction in changeover time from 94 to 24 minutes was achieved in the case of the stamping operation by carrying out a single-minute exchange of die (SMED) and by changing internal activities to external activities. The same approach was also recommended to be carried out for the shearing operation. The changeover time for the powder coating operation was eliminated as a new dedicated setup was proposed and implemented.

In summary, the proposals and modifications made to the production system resulted in four 'batch' operations (i.e., shearing, bending, stamping, pre-treatment) and two areas of the process with continuous flow (i.e., cell production). For the batch operations, an optimum amount of batch was defined and kanban systems implemented for their control.

According to the systematic method proposed by Rother and Shook (1999) to develop the future state map, a 'pacemaker' operation and a 'pitch' time for the pacemaker operation had to be defined. The pacemaker step should be such that all process downstream of it should have continuous flow (Rother and Shook, 1999). As evident in the future state map presented in Figure 3, the power coating + painting + drying cell qualified as the pacemaker step; it cannot be any step upstream of this because pretreatment is using a batch approach and not producing to continuous flow. Thus, in the future state it was determined to be the power coating + painting + drying cell those that regulated production. Thus, the PPC department only had to schedule this cell, based on customer demand. This improved the information flow of the whole manufacturing system. In the case of the 'pitch' time, it was defined to be 90 minutes. This meant that 90 minutes was taken as a management time frame to review the manufacturing process. 
Figure 3 Future state value stream map (see online version for colours)

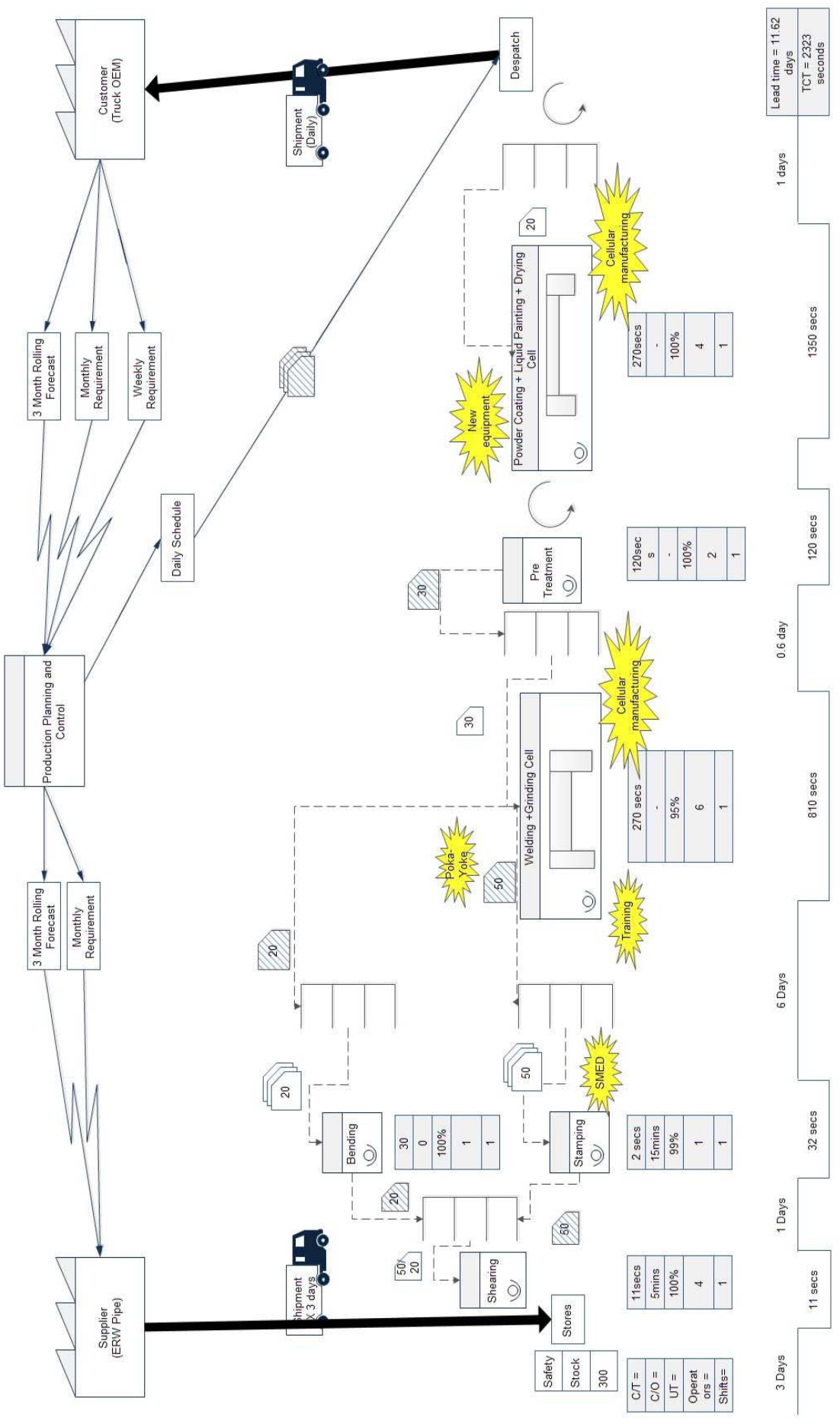




\section{Conclusions}

The manufacturing industry in India today is ever growing, and to remain competitive and grow alongside this industry Indian manufacturing SMEs have to focus on providing high standards of QCD to their OEMs. A major factor to achieve this is a company's ability to effectively implement a philosophy that allows it to continually and systematically improve its processes and enhance its overall operational performance. Lean manufacturing is one of the leading philosophies used by a number of organisations worldwide to improve and enhance their overall operational performance (Taj, 2008). However, the academic literature indicates that the application of lean principles and tools in the Indian manufacturing industry, especially among SMEs, is limited. In particular, although there is evidence that some manufacturing companies in India have adopted lean manufacturing practices and VSM as improvement approaches, several studies and authors argue that this application is either feeble or has not been fully successful. Thus, this paper provides evidence that nowadays the application of lean manufacturing in the Indian manufacturing sector is growing, and that its successful implementation could represent an important strategy for SMEs to meet the challenges of a growing industrial market.

In particular, this paper presents a successful application of the lean manufacturing VSM approach to reduce the production lead time, inventory, changeover time and align all the process operations to the customer demand (i.e., takt time) of an India manufacturing SME fiercely competing in several industrial sectors. In this context, the production lead time was reduced from 49days/8147 seconds to 11.6 days/2323 seconds. This reduction in lead time has helped the organisation studied to ensure that it provides better service levels for its customers and reduce inventory from its value stream. In terms of inventory, WIP was reduced from 28.15 days to 7.6 days while raw material was also reduced from 20.69 days to three days. This was achieved by implementing a pullbased material system and re-arranging some of the process operations into cells, which provided continuous flow. Enhancing the company's relationship with its suppliers also was a key factor to reduce the WIP inventory in all operations and in the store (i.e. raw material - safety stock). As a result, the company has been able to reduce its operational cost and improve its quality. However, the inventory of finished goods increased from 0.6 days to 1 day. This was a strategic decision taken by the organisation studied to be able to timely meet the customer demand. In the current state there were 5 bottleneck operations based on the takt time of 270 seconds. These bottlenecks were removed by undertaking the improvement actions previously discussed in Section 4. Finally, important reductions in changeover times were also achieved as explained in Section 4.

This study was based on the review and improvement of the manufacturing process of a single and specific product family from the sheet metal division of the organisation studied. The results of this study open various avenues that can be subjects of future research and a deeper study, for example:

1 further research can be carried out to support the improvements already made by using simulation to prove/disprove whether the operation parameters proposed and implemented were the optimum ones

2 the study focused on the value stream of the organisation studied, the same can be extended to include its suppliers 
3 as the organisation studied manufactures products in various categories other than the one studied, further research can be carried out to use VSM for products from other categories.

\section{References}

Abdulmalek, F. and Rajgopal, J. (2007) 'Analyzing the benefits of lean manufacturing and value stream mapping via simulation: a process sector case study', International Journal of Production Economics, Vol. 107, No. 1, pp.223-236.

Anand, G. and Kodali, R. (2008) 'Selection of lean manufacturing systems using the PROMETHEE', Journal of Modelling in Management, Vol. 3, No. 1, pp.40-70.

Baines, A. (1995) 'Work measurement - the basic principles revisited', Work Study, Vol. 44, No. 7 , pp.10-14.

Band, W.A. (1991) Creating Value for Customers, Wiley, New York, NY.

Bhamu, J., Shailendra, K. and Sangwan K.S. (2012) 'Productivity and quality improvement through value stream mapping: a case study of Indian automotive industry', International Journal of Productivity and Quality Management, Vol. 10, No. 3, pp.288-306.

Brunt, D. (2000) 'From current state to future state: mapping the steel to component supply chain', International Journal of Logistics: Research and Applications, Vol. 3, No. 3, pp.259-271.

Chen, J., Li, Y. and Shady, B. (2010) 'From value stream mapping toward a lean/sigma continuous improvement process: an industrial case study', International Journal of Production Research, Vol. 48, No. 4, pp.1069-1086.

Chernatony, L., Harris, F. and Riley, F. (2000) 'Added value: its nature, role and sustainability', European Journal of Marketing, Vol. 24, Nos. 1/2, pp.39-56.

Dankbaar, B. (1997) 'Lean production: denial, confirmation or extension of sociotechnical systems design?', Human Relations, Vol. 50, No. 5, pp.567-584.

Dhandapani, V., Potter, A. and Naim, M. (2004) 'Applying lean thinking: a case study of an Indian steel plant', International Journal of Logistics Research and Applications: A Leading Journal of Supply Chain Management, Vol. 7, No. 3, pp.239-250.

Eswaramoorthi, M., Kathiresan, G., Prasad, P. and Mohanram, P. (2011) 'A survey on lean practices in Indian machine tool industries', The International Journal of Advanced Manufacturing Technology, Vol. 12, Nos. 9-12, pp.1091-1101.

Gale, B.Y. (1994) Managing Customer Value, Creating Quality and Service that Customers Can See, The Free Press, New York, NY.

Garza-Reyes, J.A., Parkar, H.S., Oraifige, I., Soriano-Meier, H. and Harmanto, D. (2012) 'An empirical exploratory study of the status of lean manufacturing in India', International Journal of Business Excellence, Vol. 5, No. 4, pp.395-412.

Ghosh, M. (2013) 'Lean manufacturing performance in Indian manufacturing plants', Journal of Manufacturing Technology Management, Vol. 24, No. 1, pp.113-122.

Gurumurthy, A. and Kodali, R. (2011) 'Design of lean manufacturing systems using value stream mapping with simulation: a case study', Journal of Manufacturing Technology Management, Vol. 22, No. 4, pp.444-473.

Hines, P., Rich, N., Bicheno, J., Brunt, D., Taylor, D., Butterworth, C. and Sullivan, J. (1998) 'Value stream management', International Journal of Logistics Management, Vol. 9, No. 1, pp. $25-42$.

Houten, M.P., Garza-Reyes, J.A., Oraifige, I., Soriano-Meier, H. and Rocha-Lona, L. (2012) 'Implementing value stream mapping (VSM) in a world-class organisation', Proceedings of the International Conference in Engineering and Technology for Sustainable Development (IETSD), 3-5 September, Vol. 1, pp.65-71, Tamil Nadu, India. 
Khan, Z., Bali, R.K. and Wickramasinghe, N. (2007) 'Developing a BPI framework and PAM for SMEs', Industrial Management and Data Systems, Vol. 107, No. 3, pp.345-360.

Kilpatrick, J. (2003) Lean Principles, Manufacturing Extension Partnership, MEP, Utah.

Kumar, M., Antony, J., Singh, R.K., Tiwari, M.K. and Perry, D. (2006) 'Implementing the Lean Sigma framework in an Indian SME: a case study', Production Planning and Control, Vol. 17, No. 4, pp.407-423.

Lasa, I., Laburu, C. and Vila, R. (2008) 'An evaluation of the value stream mapping tool', Business Process Management Journal, Vol. 14, No. 1, pp.39-52.

Lovelle, J. (2001) 'Mapping the value stream', IIE Solutions, Vol. 33, No. 2, pp.26-33.

Manos, T. (2006) 'Value stream mapping - an introduction', Quality Progress, Vol. 39, No. 6, pp.64-69.

McDonald, T., Aken, E.M. and Rentes, A.F. (2002) 'Utilising simulation to enhance value stream mapping: a manufacturing case application', International Journal of Logistics Research and Applications: A Leading Journal of Supply Chain Management, Vol. 5, No. 2, pp.213-232.

Naumann, E. (1995) Creating Customer Value: The Path to Sustainable Competitive Advantage, Thomson Executive Press, Cincinnati, $\mathrm{OH}$.

Rajenthirakumar, D. and Thyla, P. (2011) 'Quality and productivity improvement in automotive component manufacturing company using Kaizen', Manufacturing and Industrial Engineering, No. 2, pp.36-38.

Ramesh, V., Prasad, K. and Srinivas, T. (2008) 'Implementation of a lean model for carrying out value stream mapping in a manufacturing industry', Journal of Industrial and Systems Engineering, Vol. 2, No. 3, pp.180-196.

Rother, M. and Shook, J. (1999) Learning to See, Lean Enterprise Institute Inc., Brookline, MA.

Sahoo, A., Singh, N., Shankar, R. and Tiwari, M. (2008) 'Lean philosophy: implementation in a forging company', International Journal of Advanced Manufacturing Technology, Vol. 36, Nos. 5/6, pp.451-462.

Seth, D. and Gupta, V. (2005) 'Application of value stream mapping for lean operations and cycle time reduction: an Indian case study', Production Planning and Control, Vol. 16, No. 1, pp.44-59.

Shingo, S. (1997) A Study of the Toyota Production System from an Industrial Engineering Viewpoint, Productivity Press, Cambridge.

Singh, B. and Sharma, S.K (2009) 'Value stream mapping as a versatile tool for lean implementation: an Indian case study of a manufacturing firm', Measuring Business Excellence, Vol. 13, No. 3, pp.58-68.

Singh, B., Garg, S.K. and Sharma, S.K. (2010) 'Scope for lean implementation: a survey of 127 Indian industries', International Journal of Rapid Manufacturing, Vol. 1, No. 3, pp.323-333.

Singh, K. and Ahuja, I.S. (2012) 'Justification of TQM-TPM implementations in manufacturing organisations using analytical hierarchy process: a decision-making approach under uncertainty', International Journal of Productivity and Quality Management, Vol. 10, No. 1, pp.69-84.

Slack, N., Chambers, S. and Johnston, R. (2009) Operations Management, 6th ed., FT/Prentice-Hall, London.

Taj, S. (2008) 'Lean manufacturing performance in China: assessment of 65 manufacturing plants', Journal of Manufacturing Technology Management, Vol. 19, No. 2, pp.217-234.

Tapping, D., Luyster, T. and Shuker, T. (2002) Value Stream Management, 1st ed., Productivity Press, New York.

Upadhye, N., Deshmukh, S.G. and Garg, S. (2010) 'Lean manufacturing in biscuit manufacturing plant: a case', International Journal of Advanced Operations Management, Vol. 2, Nos. 1/2, pp.108-139. 
Vinodh, S., Arvind, K.R. and Somanaathan, M. (2010) 'Application of value stream mapping in an Indian camshaft manufacturing organisation', Journal of Manufacturing Technology Management, Vol. 21, No. 7, pp.888-900.

Womack, J. (2006) 'Value stream mapping', Manufacturing Engineering, Vol. 136, No. 5, pp.145-156.

Womack, J., Jones, J. and Roos, D. (1990) The Machine that Changed the World, Macmillan Publishing, New York, NY. 